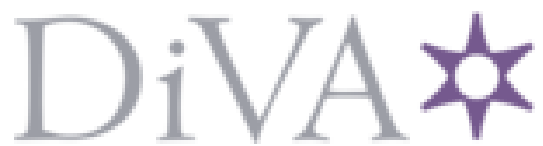

http://www.diva-portal.org

This is the published version of a paper published in International Criminal Justice Review.

Citation for the original published paper (version of record):

Ceccato, V., Abraham, J., Lundqvist, P. (2021)

Crimes Against Animal Production: Exploring the use of Media Archives

International Criminal Justice Review, 31(4): 384-404

https://doi.org/10.1177/10575677211041915

Access to the published version may require subscription.

N.B. When citing this work, cite the original published paper.

Permanent link to this version:

http://urn.kb.se/resolve?urn=urn:nbn:se:kth:diva-305096 


\title{
Crimes Against Animal Production: Exploring the use of Media Archives
}

International Criminal Justice Review $|-2|$

(C) 202I Georgia State University (c) (i)

Article reuse guidelines: sagepub.com/journals-permissions DOI: $10.1177 / 10575677211041915$ journals.sagepub.com/home/icj

@SAGE

\author{
Vania Ceccato' (D, Jonatan Abraham', \\ and Peter Lundqvist ${ }^{2}$
}

\begin{abstract}
Swedish media have revealed an increase in crimes against animal production (CAAP) in the last decade. We investigate the nature of such crimes (especially against mink, pig, and rabbit farms), with a focus on those crimes whose suspects are animal rights groups by utilizing data from media archives from 2009 to 2019. Newspaper articles show that while vandalism and trespassing are often committed against mink farms, property crimes occur more often against pig and rabbit farms. Because there are indications that crime suspects are not a homogeneous group and express different motivations to commit CAAP, a multipronged approach is needed to prevent CAAP. The use of newspaper articles from media archives has proven to be successful for obtaining a general perspective of CAAP, but it is limited for capturing crime incidence or for investigating CAAP spatiotemporal nature when using geographical information systems. The automated usage of digital media archives should be further explored and critically assessed in future research in criminology.
\end{abstract}

\section{Keywords}

rural crime, animal rights activists, trespassing, thefts, geographical information systems (GIS), newspaper articles

\section{Introduction}

"We came home after lunch and there was a sticker from the animal rights activists on our door...lots of animals were missing. They burgled freezers and refrigerators and vandalized our property: on windows, doors, gate, courtyard, house, bike... a symbol on the inside of the stable door warned: 'The Animal Liberation Front sees you'" (an animal farmer reporting a burglary on the property in a case reported by a local Swedish newspaper in 2018).

\footnotetext{
'Department of Urban Planning and Environment, KTH Royal Institute of Technology, Stockholm, Sweden

${ }^{2}$ Department of People and Society, Swedish University of Agricultural Sciences, Alnarp, Sweden

Corresponding Author:

Vania Ceccato, Department of Urban Planning and Environment, KTH Royal Institute of Technology,

Teknikringen 10, 10044 Stockholm, Sweden.

Email: vania.ceccato@abe.kth.se
} 
This single example illustrates the types of threats that farmers working with animal production are experiencing in Sweden. Official statistics of crimes against farmers are highly underreported in Sweden (Ceccato et al. 2020) and in particular those crimes against animal production (CAAP). It is also difficult, in most cases, to find out why the crime was committed, or to be able to associate evidence with a particular individual or group, unless they leave symbols or signs (as described in the above example) that can be linked to them. Note that these farmers and their properties are often targets of "traditional" farm crimes as well, such as theft of livestock and other farm produce, tools and machinery, chemicals and fertilizers as well as arson, violence, and environmental wildlife offenses (Ceccato, 2016; Lantbrukarnas Riksförbund, 2012). Official records tend to miss the true magnitude of crime in more remote areas because detection often depends on citizen reporting practices and, for certain crimes, on routine inspections (e.g., Barclay et al., 2001; Ceccato \& Dolmen, 2011; Donnermeyer et al., 2006; Smith, 2020). When these crimes are reported in official statistics, they are limited to a small number of cases that reach court. It is not surprising that there exists little systematic knowledge about the nature of these threats, their frequency, or geography in Sweden.

In the search for a better understanding of the underlying mechanisms behind these rural crimes, we investigate the nature of victimization carried out against farmers who are specialized in animal production in Sweden using print and digitally accessible newspaper articles from media archives from 2009 to 2019. This aim is achieved by:

1. Searching and analyzing print and digital newspaper archives, which we expect to provide an insight into the specificities of CAAP in rural areas when data are unavailable.

2. Then, assessing the use of media archives as data courses to investigate the nature of victimization carried out against farmers and in combination with analytical spatial tools, such as geographical information systems (GIS) to report the geography of these offenses at the municipal level.

We focus on three types of farmers: mink, pig, and rabbits because they compose the majority of articles found in the media archives between 2009 and 2019. The article is structured as follows. Section "Theoretical Background: The Potential of media Archives and CAAP" establishes the theoretical framework for the study. Then, section "The Study Case" introduces Sweden as the study area, the data and methodology followed by results in the "Results" section, which are discussed in the "Discussion of the Results" section. Finally, before we conclude the article, we discuss possible responses for the mitigation of CAAP in rural Sweden followed by research recommendations in the "Conclusions and Recommendations" section.

\section{Theoretical Background: The Potential of Media Archives and CAAP}

The evolving literature in the last few decades has started documenting crimes against farms, but these studies have typically focused on property crimes against farmers, tractors, crops, or other produce. The literature has explored the farmers' victimization using a variety of sources, from official statistics, surveys, and media archives, from burglaries to fraud to environmental crimes, but the knowledge is limited regarding CAAP and we therefore suggest media archives as a potential source of information about the nature of CAAP when traditional official statistics are lacking or underrepresent a phenomenon.

\section{CAAP and Media Archives}

The potential of using media archives as a reference for crimes that suffer from high underreporting rates is not new in the international literature, as the media coverage can reflect public discourse 
and can be indicative of new processes that have not yet been detected by law enforcement and the criminal justice.

CAAP seems to fit this category of crimes. Many crimes against farmers go undetected because crime reporting codes for CAAP are missing. Others, if detected, may not be reported to the authorities, and a fraction of them attracts the attention of local newspapers. In the last victimization survey among farmers, half of those who were victimized did not report it to the police (Johansson, 2018) and this proportion of reporting has fallen since 2012. Furthermore, one in five has received reimbursement from insurance companies, one in five considers the time spent reporting as wasted time, and as many states that the crime investigation did not move forward.

A seminal study using media archives was conducted by Davis (1952) that confirmed that the number of newspaper articles pertaining to crime varied independently of actual crime levels, perhaps because as Reis (1999) showed, media coverage is not impartial and tends to favor particular topics, sources, and opinions over others. There have been examples of studies that showed that newspaper articles underreport some types of events, and overestimate others (Fine et al., 1998; Ghaffar et al., 2001; Marsh, 1991).

In Sweden, an analysis of media coverage was conducted and compared with official police statistics for environmental and wildlife crimes (Ceccato \& Uittenbogaard, 2013; Stassen \& Ceccato, 2020). Authors expected that media coverage by local newspapers would be faster in capturing potential whistleblowers than official data sources (when reporting an environmental crime) but this initial hypothesis was not confirmed when official crime data was compared with media coverage. Findings showed that media coverage varied over time and across the country and indicated a degree of mutual influence and interdependence between the two. However, authors concluded that the assessment of the article's content served as a data source to build up a basic understanding of the nature of environmental crimes (when, where, and how) as well as the negative impact that these crimes had on the environment as well as on those involved.

The increasing amount of media information as newspapers and social media entries demand new ways of data processing, in a form of automation and specific machine learning algorithms that can be useful for criminology and crime prevention, constituting a new research frontier in this area (e.g., Umair et al., 2020).

\section{What is CAAP?}

CAAP can take different shapes and affect farmers in different ways. In Sweden, media reports show examples of threats, damage, trespassing, tampering, robberies, and other criminal acts directed not only against farm property and activities but also against the farmers themselves, their family members, and employees (e.g., Bergström, 2019). The increasing levels of theft that affect farmers (ATVs, farm tractors, machines, tools, pesticides, fuels, and other farm assets) have also become a more frequent occurrence in the Swedish countryside (Ceccato, 2016; Ceccato \& Dolmen, 2011) and are motivated by financial gain. However, the motivations behind CAAP vary widely depending on the type of offense and the context in which it is committed. Some crimes have been directed to particular groups of farmers, their employees, and properties, exposing them to various forms of abuse and injuries (Verdicchio, 2019). A particular case are pollitically motivated and constitute of actions that go under the umbrella term "criminal animal rights activism". According to the Swedish Centre for Preventing Violent Extremism, criminal animal rights activism is constituted of "individuals and groups who consider violence to be a legitimate means of achieving animal rights policy goals" (CVE, 2020, pp.3-5). These behaviors involve arson and vandalism against property but may also include violence directed at people. The use of force is justified by the idea of "extended right to self-defence," which means that activists, on behalf of the animals, exercise the animals' alleged right to protect themselves from violence and abuse. "The Swedish pro- 
violence animal rights movement consists of activist groups that are to varying degrees independent of each other but which organize themselves on the basis of common ideological positions" (CVE, 2020 , pp. 3-5). The extent and form of crimes against animal farmers vary by different groups and individuals, but the crimes are often related to violent acts, often linked to a broader transnational movement in which different actors and/organizations carry out similar actions around the world.

To contextualize these motivations further, the human-animal relationship has long been a controversial subject and public opinion has varied greatly through times (see, e.g., Anderson, 1997; Philo \& Wilbert, 2000; Yarwood \& Evans, 2000). The transition into agribusiness and factory farming has led to greater and more normalized exploitation of animals, which in turn has led to animal rights and welfare becoming a higher priority in many countries. The European Union has certain directives regarding animal welfare that must be followed, but allows member states to adopt stricter rules if compatible, meaning that animal welfare laws can vary greatly in Europe (European Commission, n.d.). In Sweden, the welfare of farm animals has often been cited as being of high standard and regulations are much stricter than most other countries (Jordbruksverket, 2021), but has also received criticism on occasion both from animal rights advocates and other farmers (e.g., the "Pig Scandal," detailed later in this paper). Animal rights activists have claimed that despite routine animal welfare inspections it is clear from their (unlawful) documentation of farms that the regulations and laws are not always followed (Efendic, 2009), which can, for some, further blur the line of who the real offenders and victims are.

In summary, for profit-motivated CAAP such as theft of livestock or machinery that are motivated by financial gain, of particular importance are the notions of opportunity, guardianship, and accessibility. For politically motivated CAAP such cases in which the suspects are said to be linked to illegal animal rights activists, the theory around "techniques of neutralization" provides an insight into how individuals and organizations justify the decision to commit crimes (Schoultz \& Flyghed, 2016; Sykes \& Matza, 1957; Whyte, 2016). In the next section, we discuss these theories more in detail.

\section{Motivations of CAAP}

As with any crime, CAAP depend on the interactions between individuals' propensity and motivations and the situational conditions. Whether a person commits a crime or not is not intrinsic to the perpetrator, but arises from circumstantial factors: the presence of a potential victim, of a likely perpetrator, and the absence of a guardian (Cohen \& Felson, 1979), as suggested by the routine activity approach. For example, Donnermeyer et al. (2011) suggest that farms tend to experience higher rates of theft when equipment and machinery are stored at isolated locations, where there are few people and some distance to the main operations. The authors also point out that these conditions may vary by type of crime. Those farms that were situated near a public road but were relatively remote from urban settlements were more likely to experience trespassing, vandalism, and illegal dumping. They also suggest that farms encompassing difficult terrain, such as in mountainous areas, were most likely to suffer trespassing, poaching, and livestock theft, as reported by Barclay and Donnermeyer (2002). The authors also suggest that if a farm was situated in close proximity to main routes and/or urban centers, the result was an increased likelihood of becoming a victim of crime. Studies by Barclay and Donnermeyer (2007) and Mears et al. (2007) provide evidence of these hypotheses. Studies that looked at waste dumping in a rural Swedish county corroborate the idea that easier accessibility to a place makes it easier to dump cars and waste but also makes it easier for transients to detect and report these crimes (Ceccato \& Uittenbogaard, 2013). In addition, the situational conditions of farm crime are also affected by time of the day, day of the week, or season. The winter season, when fewer people are working on farms, may provide better opportunities for theft than summer, when more people are needed to work. As the temporary population does not establish long-term 
social ties to the permanent population, farms and rural communities may become more at risk (Barclay et al., 2001).

The central question is what kind of people commit what kind of crime in what kind of places and why. The basic argument in situational action theory is that people commit crimes when they perceive a criminal act as an acceptable course of action in a given circumstance or if they are unable to act in accordance with their personal morality (exercise self-control) when exposed to external influences to act in its opposite (Wikström, 2006). The situational mechanism explains why crime occurs, while selection mechanisms explain why criminogenic situations arise. A farm's possessions can help explain the victimization risks that help explain the situational mechanisms. For example, owning a truck or tractor (of a particular model) may increase a farmers' overall risk of becoming a crime target. Yet, not all products are equally at risk of theft because thieves select what they will steal. Some of the key attributes of crime targets are their value, size, and portability, which can be summarized by CRAVED, an acronym referring to hot products that are concealable, removable, available, valuable, enjoyable, and disposable (easy to sell) (Clarke, 1999).

Finally, the so-called techniques of neutralization can be useful to facilitate the understanding of the motivations for politically motivated CAAP. Sykes and Matza (1957) describe techniques of neutralization by which people rationalize criminal behavior to temporarily neutralize certain values within themselves, which would normally prohibit them from carrying out such acts, such as an obligation to abide by the law. This can also be expressed through denial of responsibility by shifting blame to another party, or denial of injury by arguing that their actions caused no substantive harm. The perpetrators might believe that the animal farmer "deserved" whatever action they committed (denial of the victim) because they were badly treating animals. Yet another example of these rationalizations could allow the perpetrator of CAAP to appeal to "higher loyalties," arguing that their criminal actions, although illegal, are justified "for the greater good"-for example, when animal rights activists trespass on, break into and/or vandalize property, and threaten farmers to defend the welfare of animals.

\section{Research Questions}

We inspected media archives to cast light on the following research questions:

1. Which are the most common CAAP reported in newspapers articles? (Type, frequency, location, and potential mechanisms)?

2. What is the spatiotemporal nature of CAAP depicted using media archives as data courses?

3. Which are the opportunities and challenges in using media archives as data courses to investigate CAAP and in combination with GIS?

\section{The Study Case}

In 2018, there were 61,154 agricultural enterprises in Sweden (SCB, 2019), in a country with 10 million inhabitants, and one of the largest land areas in Europe. As much as $86 \%$ of this population is classified as urban-dwelling by the World Bank (2018). The country is divided into 21 counties and 290 municipalities, the latter of which are the unit of analysis for this study. Of these municipalities, 112 are classified as urban areas (total population $\sim 7$ million), 156 as accessible rural (total population $\sim 3$ million), and 22 as remote rural (total population $\sim 140,000$ ).

Note that there is no agreement on exactly how many animal-producing enterprises exist in Sweden. One estimate indicates 17,800 enterprises, out of which $\sim 8,600$ are full-time farmersbroken down into different types, sometimes with different animals; for example, around 3,300 
milk producers and 1,000 pig farms (Swedish Board of Agriculture, 2019; SCB, 2019). While pig farmers are decreasing in numbers, from 6,014 farmers in the $2000 \mathrm{~s}$ to 1,346 in 2018 with a swine population of more than a million animals (Jordbruksverket, 2018). In August 2018, the Association of Rabbit Producers had 170 producers as members. A preliminary estimate of the annual slaughter at registered slaughterhouses is in the order of 30,000 animals as a source of meat for the domestic market (LRF, 2020). There are about 80 mink farmers, and an estimated 1,000 people are employed in the industry, making the country the fifth-largest producer in Europe (Svenskmink, 2020).

\section{Data and Methods}

Data was collected using the Swedish national media archives (Research Mediarkivet), a resource provided by university libraries. In a preliminary search, three different sets of keywords were used to find articles regarding CAAP. After this preliminary search, the scope was limited to the three most frequently mentioned types of farmers related to animal production: mink farmers, pig farmers, and rabbit farmers. Table 1 indicates the keywords chosen after the initial sampling of newspaper articles.

The time period of study was set between January 1, 2009, and December 31,2019. A tailored set of keywords was used for each of the three actors (Table 1), with the search yielding a combined total of 5,360 hits. After removing the nonrelevant articles-those describing an event outside Sweden, or that were simply not related to crimes against farmers but still included the keywords - the final sample was 1,971 news articles regarding crimes against mink, pig, and rabbit production.

Type of Content. First, the relevant articles were divided into three different categories based on the type of content. First-degree articles are closely related to a specific crime event and place (it would be equivalent to a recorded crime if reported). The first article of this degree adds to the total count of unique cases for each respective type of farmer. Second-degree articles are articles that are less linked to the crime event or describe multiple events and/or places; they can be about following up on the investigations of different cases, a summary of crimes in a region, etc. Third-degree articles entail a more general discourse on crimes against farmers. These can be debate articles or general information on the problem and are often on a national level. Using spreadsheets, the information from articles was systematically categorized according to a number of dimensions later used as a basis for producing the graphs and maps presented in the "Results" section. The dimensions include the degree, the publishing date, the annual number of articles, and the location of the cases by municipality, which were later imported into GIS.

Table I. Keywords Used in the Search for Crimes Against Animal Production (CAAP) Articles in Media Archives 2009 to 2019.

\begin{tabular}{ll}
\hline $\begin{array}{l}\text { Type of } \\
\text { farmer }\end{array}$ & Keywords \\
\hline Mink farmer & $\begin{array}{c}\text { (minkfarm* OR minkbonde* OR minkuppfödare* OR minkgård*) AND (hot OR misshandel } \\
\text { OR sabotage OR mordbrand OR intrång OR hemfridsbrott OR inbrott OR vandalisering OR } \\
\text { skadegörelse OR trakasserier OR ofredande OR stulen OR stöld) }\end{array}$ \\
$\begin{array}{c}\text { Pig farmer } \\
\text { (grisbonde* OR grisgård* OR grisfarm* OR svingård*) AND (hot OR misshandel OR sabotage } \\
\text { OR mordbrand OR intrång OR hemfridsbrott OR inbrott OR vandalisering OR skadegörelse }\end{array}$ \\
$\begin{array}{c}\text { OR trakasserier OR ofredande OR stulen OR stöld) } \\
\text { (kaninfarm* OR kaningård* OR kaninuppfödare* OR kaninbonde* OR kaninproducent*) AND } \\
\text { (hot OR misshandel OR sabotage OR mordbrand OR intrång OR hemfridsbrott OR inbrott } \\
\text { OR vandalisering OR skadegörelse OR trakasserier OR ofredande OR stulen OR stöld) }\end{array}$ \\
\hline
\end{tabular}


From the first-degree articles, events were classified by type of crime and tallied for each type of farmer, namely unlawful threat, assault, arson, theft/burglary, trespassing, vandalism/physical damage/graffiti, and animal abuse. Two types of crimes were counted as a combination of two offenses: theft/burglary and trespassing/“Hemfridsbrott" (the latter can be translated as disturbance of the domiciliary peace). This is because news articles do not always describe enough details to differentiate between them. While crimes such as fraud have been noted to be a common offense directed at farmers, it was not as explicitly connected to situational conditions of farms and was also not appearing as frequently in media coverage.

Temporal and Geographical Data. The methodology of analysis for this study is divided into parts: (1) we assessed the temporal and spatial trends of CAAP and then (2) we used a detailed analysis of newspaper article content to provide insight into the nature and causes of CAAP. The articles were sorted by publishing date, and the annual number of articles was calculated to enable the viewing of variation and peaks over the chosen time period, as well as the monthly count of observed unique cases. Finally, the location of the cases found in the articles was recorded by municipality. The municipal data together with data on the offenses was restructured in Microsoft Excel sheets and later exported into the GIS-based program ArcMap. The Excel sheets were joined with a shape-file with municipal data of Sweden. This process was repeated for each type of farm (mink, pig, and rabbit) separately. With this, the geographical distribution of the articles could be visualized. The aggregate map depicts 290 Swedish municipalities with shading to indicate the municipalities that had at least one CAAP article.

\section{Results}

\section{The Nature, Frequency, and Location of CAAP}

The total number of relevant articles extracted from media archives from 2009 to 2019 was 1,971. Out of this total, 25\% were first-degree articles (Figure 1a): 7\% were single cases of crimes $(n=137$, Table 2) and 18\% of these articles included for instance duplicates (articles of the same case in other newspapers, $n=363$ ). Typical headlines of this degree included "Vandalism at mink farm in Kind (Västra Götaland)," "Stole 33 rabbits in burglary," or "30 pigs stolen in Säter" (Table 3). Second-degree articles $(35 \%, n=585)$ were following up on the investigations or summarizing crimes in a region. Headlines included "Request to start mink farm is withdrawn after threats"; "She doesn't see an end to the activists' harassment"; and "Pig verdict appealed." These articles were included to provide insight into how many cases were followed up on in media and continuously reported on to the public. Finally, the third-degree articles $(45 \%, n=886)$ entailed a more general discourse on crimes against farmers. Typical headlines, in this case, were: "Politicians

Table 2. Crimes Against Animal Production (CAAP) Counts and Percentages According to Media Archives Articles 2009 to 2019.

\begin{tabular}{|c|c|c|c|c|c|c|c|c|}
\hline Type of crime & $\begin{array}{l}\text { Unlawful } \\
\text { threat }\end{array}$ & Vandalism & Assault & $\begin{array}{l}\text { Trespassing/ } \\
\text { home invasion }\end{array}$ & $\begin{array}{l}\text { Animal } \\
\text { abuse }\end{array}$ & Arson & $\begin{array}{l}\text { Theft/ } \\
\text { burglary }\end{array}$ & Total \\
\hline $\begin{array}{c}\text { Counts of } \\
\text { articles }\end{array}$ & 16 & 35 & 3 & 47 & 6 & 5 & 25 & 137 \\
\hline $\begin{array}{l}\text { Percentage } \\
\text { (\%) }\end{array}$ & 12 & 26 & 2 & 34 & 4 & 4 & 18 & 100 \\
\hline
\end{tabular}




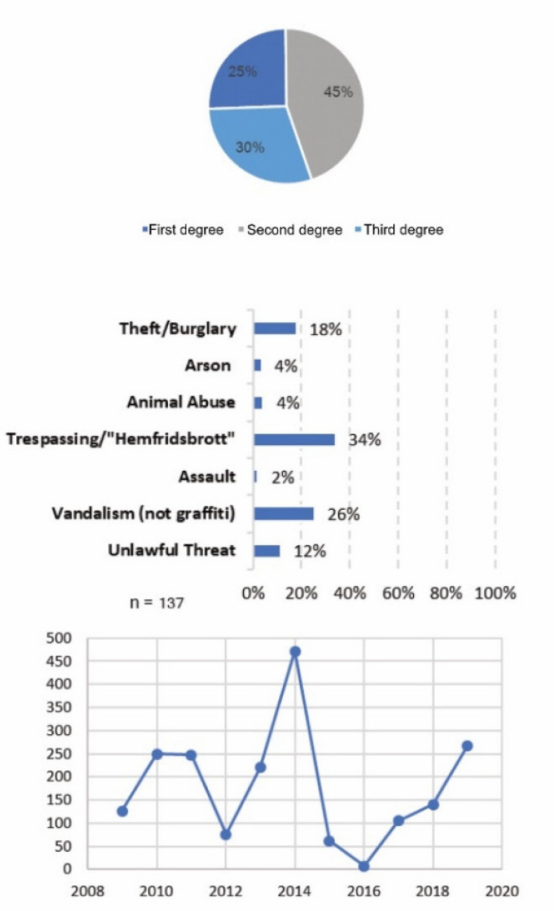

(a)

(b)

(c)
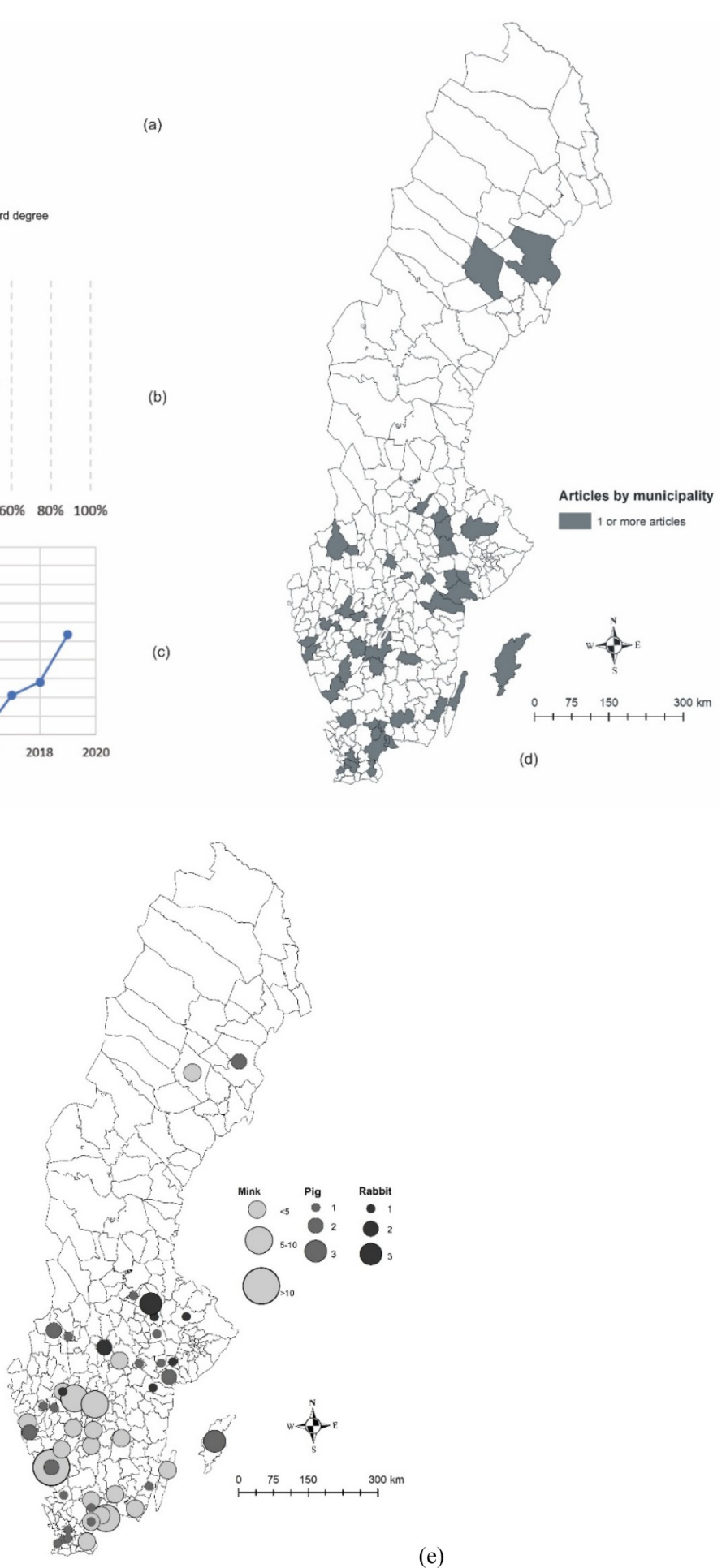

(e)

Figure I. (A) Total media articles by type in crimes against animal production (CAAP; \%). (b) Distribution of offenses by type and percentage. (c) Counts of articles by year. (d) Media articles by the municipality, and (e) by types of animal production: minks, pigs, and rabbits, 2009 to 2019. Source: Authors. 
Table 3. Types of Articles About Crimes Against Animal Production (CAAP) Classified by Type and Relevance 2009 to 2019.

\begin{tabular}{lll}
\hline Type of farmer & Type of article & Article title \\
\hline Mink farmer & First-degree & "Vandalism at mink farm in Kind (Västra Götaland)" \\
& Second-degree & "Request to start mink farm is withdrawn after threats" \\
& Third-degree & "Politicians ignore animal activist extremism" \\
Pig farmer & First-degree & "Pig piglets stolen in Säter" \\
& Second-degree & "Pig verdict appealed+" \\
Rabbit farmer & Third-degree & "Stole 33 rabbits in burglary" \\
& First-degree & "She doesn't see an end to the activists' harassment" \\
& Second-degree & "Make punishments harsher for activism" \\
\hline
\end{tabular}

ignore animal activist extremism," "Make punishments harsher for activism," and "Mass media condemned innocent pig farmers."

The articles indicate that the animal rights activists linked to these crimes are not a homogeneous group. They share the same interest in and passion for the rights of animals, but they do not always share a common idea of what means are legitimate in defending animal welfare. There are those who only demonstrate. Some are willing to go further, for example, civil disobedience or stealth filming through trespassing. Finally, there are also those who threaten farmers and are prepared to use violence against farmers and police "to defend the animals" against allegedly animal abuse. The police believe that this last category of activists is restricted to a few individuals in Sweden.

Figure 1c and e portray the temporal and geographic patterns of all media articles (i.e., mink, pig, and rabbit production), and how they differ by municipality. Trespassing and home invasion (in Swedish, hemfridsbrott) make up the largest share of the crimes, 34\% (Figure $1 \mathrm{~b}$ and Table 2). In almost all of these articles, animal rights activists were named, either as suspected offenders or as perpetrators through proof or admission of guilt. Interestingly, there are also cases of animal abuse, theft of pelts, and animals being killed in transit by the suspects who broke into the farm and released the animals. The animal rights activists that were mentioned in such articles seem to be connected to specific activist organizations such as the Animal Rights Alliance.

A total of 46 different municipalities had at least one CAAP-related article (16\% of the total). The majority of articles are linked to the center to southern parts of Sweden (Figure 1d and e), where most animal production is located. There were two exceptions in the north: Skelleftea municipality (against pig farms) and Lycksele municipality (sabotage at a mink farm), both in 2009. Falkenberg municipality, in Southwest of Sweden, had the highest coverage with 16 articles, the majority of which were related to attacks on mink production and to a lesser extent, on pig farms, followed by Sölvesborg municipality with 10 articles (all on mink production), then Hjo and Kumla municipalities with seven articles each (also all on mink production).

The motivations behind these crimes vary; some are financial, others are political, and still, others are, for example, sadistic. Thefts and burglary are more common against pig and rabbit production than mink production, most likely because some are stolen for profit. Raised for both fur and meat, rabbits can have a high perceived value which may motivate crimes such as theft and burglary. In 2019, the police estimated a rabbit's value at 1000 SEK each (SvD, 2019). The monetary gain seems to also be a relatively common motivation for offenders stealing other valuable goods such as mink pelts. However, occasionally, these articles have also reported sadist behavior, with animals having been killed for no other discernible reason. A number of cases referred to thefts of pigs that were later killed near the sites of the crimes, both on the Swedish island of Gotland in 
2011 and 2012. Another case in the municipality of Arvika in 2017 pertains to four pigs with slashed genitals (Swanö, 2017), and in the municipality of Sala in 2019, 10 rabbits were found beaten to death outside a farm, with an additional 30 rabbits gone missing (SvD, 2019).

Articles frequently mentioned other motivations, such as the expressed goal to make the farmers shut down their operations, manifested via threats and direct attacks against especially mink and rabbit farmers. In Hjo municipality in 2013, a mink farmer, his relatives, and accountant repeatedly received death threats via symbolic attacks, such as having a tombstone thrown into their yards as well as axes thrown through their windows. The attacks continued for several years until the farmer decided to shut down the mink operation, partly due to diminished economic viability and partly due to the attacks (Weimar, 2018). In Avesta municipality in July 2018, activists accused rabbit farmers of neglect as they had found dead rabbits. The farmers accused the activists of having planted the dead rabbits themselves and reported them for disturbing the peace as they had apparently trespassed while protesting (Leander, 2018).

As for the temporal variation of CAAP, two major peaks of newspaper articles were observed for pigs and rabbits (one peak per type of animal) when the data was collapsed for the 10 years. For pigs, the peak was from October to December while for rabbits it was during the spring, in April and May. This crime variation is difficult to associate with seasonal patterns of consumption or actions of animal rights activism but for pigs, for example, it may be linked to an increase in demand for pork products leading up to Christmas.

\section{Crimes Against Mink Farms}

Mink farms were by far the most common target for crime according to newspaper articles from 2009 to 2019 (a total of 1580 articles described 55 cases with 87 crimes, 26\% of which articles were first-degree articles; see Figures 2 and 3). Figure 2 shows that $75 \%$ of articles are not first-degree articles about specific cases of crimes against mink production but rather on following up investigations or the general discourse on CAAP (second-degree articles compose nearly half of the total). Most of the reported events are in the southern parts of Sweden and along the coasts. Vandalism followed by trespassing were the most common types of crimes against mink farms (Figure 3) but also theft and burglary, as well as unlawful threats, but to a lesser degree. In 2014, an abnormally high peak can be observed as almost $30 \%$ of all articles on crimes against mink production were published that year (Figure 4).

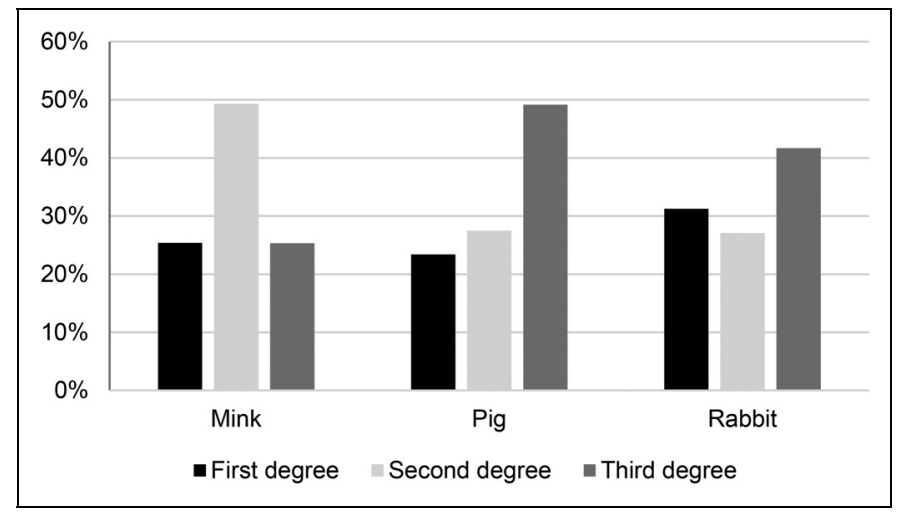

Figure 2. Type of media articles against each type of farmer working with animal production crimes against animal production (CAAP; $n_{\text {mink }}=1580, n_{\text {pig }}=295, n_{\text {rabbit }}=96$ ), 2009 to 2019. 


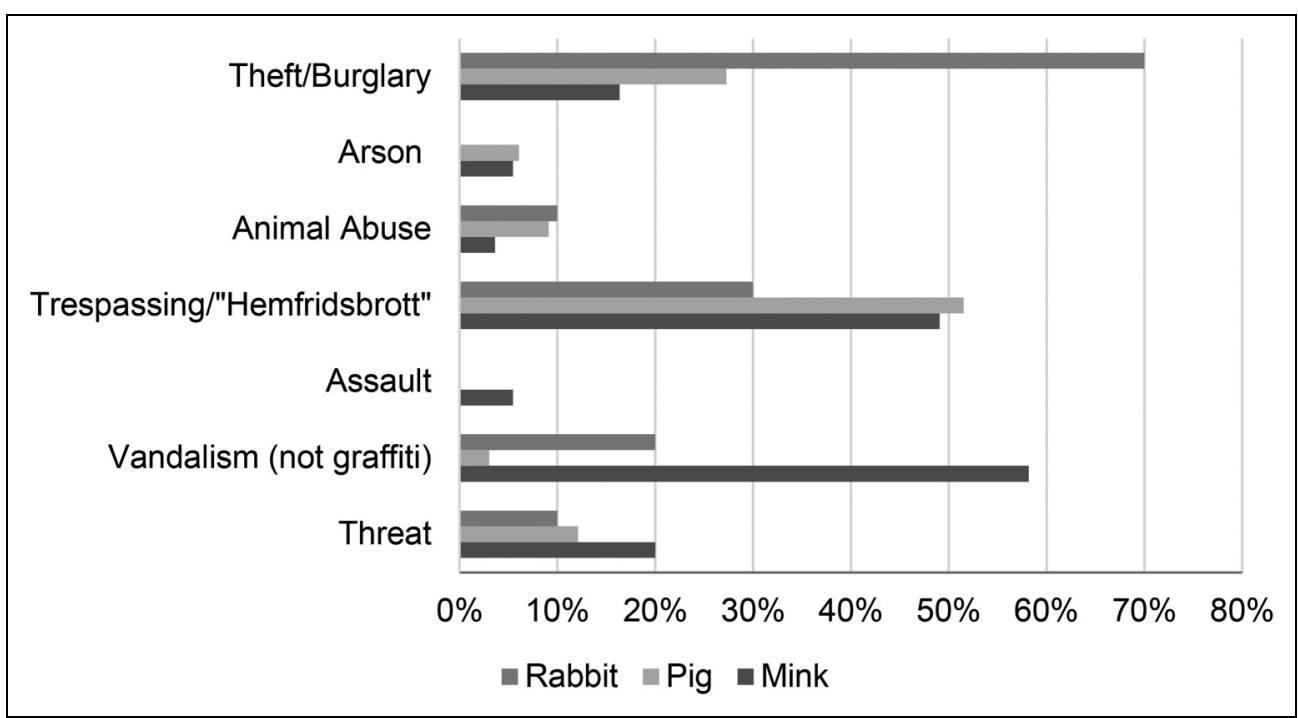

Figure 3. Estimation of offenses from media archives directed to crimes against animal production (CAAP), 2009 to $2019\left(n_{\text {mink }}=55, n_{\text {pig }}=36, n_{\text {rabbit }}=11\right)$.

Results of the media analysis indicate that crimes against mink farms do not happen at random. Rather, they follow particular situational patterns in which accessibility and anonymity play important roles in making certain municipalities easier targets than others. The municipalities Falkenberg, Sölvesborg, and Hjo had the highest counts of unique articles, in descending order. While not always discernible based on the limited information in the articles, there were indications of near-repeat victimization against farms sharing similar characteristics. From the articles, there are also indications of strong cohesiveness of these mink farmers in Sölvesborg municipality (in local organizations, e.g., Svensk mink or Kanin producenterna) which may also attract animal rights activists to target this particular area. The targeted municipalities are mainly localized relatively close to more urbanized parts

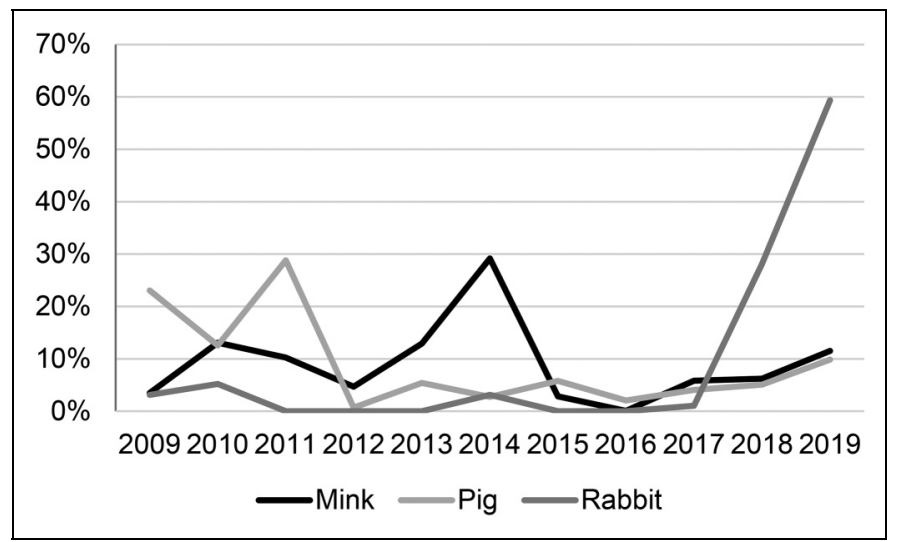

Figure 4. Number of articles per year (percentages of counts per actor) $n_{\text {mink }}=1580, n_{\text {pig }}=295$, $n_{\text {rabbit }}=96$. 
of Sweden and are therefore relatively easy to access. For example, the most affected municipalities are also by Swedish standards larger municipalities and close to larger towns.

Yet, the farms are located in places that promote the necessary anonymity for crime to happen. Another example of the importance of situational conditions took place in 2010 when 17,000 minks were released from their cages (Swedish Radio, 2014). Earlier that year, an animal activist group had protested outside the farm in question, but they denied any involvement in the incident despite expressing support for the attack. Despite a large number of animals released, the crime was not detected until some of the animals were killed by cars on roads nearby.

Although there were no clear differences of when these crimes took place during the year, the majority of the crimes were described to have happened at night, especially crimes such as vandalism, arson, theft, and burglary. Although many of the articles did not provide detailed information of the timing of events, the findings indicate that daytime crime events were mostly related to acts such as activist protests outside farms that had led to disturbance of the peace or trespassing charges and in a few cases assault.

\section{Crimes Against Pig Farms}

Trespassing composes the majority of crimes against pig farms, in some cases together with theft that comprises $27 \%$ of the cases described in the articles. As many as 295 articles describing 33 cases were found related to pig farmers and pig production, with $29 \%$ articles ( 85 articles) published in 2011 (Figure 4). Multiple articles were related to a general debate over if the activists were right in trespassing to expose alleged animal neglect (Figure 2), which initially generated large support for the activists. The activist group argued that they "had only entered where the doors were unlocked" and that they had not interfered in any other way, implying that they felt provoked in their actions by the situational conditions of the farm (Efendić, 2009).

The geography of the crimes described in these articles (Figure 1e) indicates that the island of Gotland showed a slightly higher count than the average. The island's low population density promotes anonymity, a necessary condition for thefts and trespassing. Being located in or close to relatively large municipalities may also affect the choice of target as such farms are more accessible; such as the affected pig farms in the municipalities of Arvika, Nyköping, and Skellefteå. Easy access to the barns and poor guardianship facilitated trespassing in several reported cases. Most of these trespassing events were also thought to have taken place at night. Animal farmers are encouraged to leave their barns and animal pens unlocked, to ease evacuation in case of a fire. This seems to have been exploited multiple times, especially by animal rights activists, who have trespassed onto pig farms without detection. This is illustrated in the so-called "Pig scandal" of 2009 (Efendic, 2009), when animal rights activists entered pig farms to document the pigs' living conditions. They secretly made video recordings in pig houses and then presented the films via a variety of media channels, often strategically broadcasting when people more commonly eat pork, such as the traditional Christmas ham (in Swedish julskinka) and barbeque during the summer. Over the years, activists have been releasing recordings of alleged abuse/neglect at pig farms, for example, in 2009 (the big "Pig scandal") but also in 2011, 2013, and 2019, all reported in November and December. The affected farmers were not aware of any trespassing until the activists themselves exposed their documentation through national media. Farmers' stories illustrate this seasonality around Christmas described in an article in a national newspaper:

\footnotetext{
"The fact that the Animal Rights Alliance's move was done right before Christmas is not surprising"... "Right around Christmas, there's always something like this. Always the same thing. It has been like that for as long as I have been doing this. It's an ungrateful job.” (Kruse, 2009)
} 
Pig farmers are also worried about trespassing due to the risk of spreading diseases (between farms and from elsewhere) since some farmers are serious in strictly following biosecurity recommendations, as illustrated by Nöremark et al. (2016). An example from 2019 from an article from a newspaper shows a farmer's concerns:

There are dangerous diseases that risk spreading....we receive unwanted things into our facilities. We care for the health of our animals in Sweden, that's why we are top of the class in using antibiotics as little as possible. We want to keep the infection pressure low (Ärlemyr \& Söderberg, 2019).

\section{Crimes Against Rabbit Farms}

For rabbit-related CAAP, some cases attracted a lot of media attention but there were articles following up on the investigation or following the general debate as well. A total of 96 media articles were published about crimes committed against rabbit farmers and their property between 2009 and 2019 , from which 11 cases could be identified, translating to roughly $11 \%$ of the articles concerning a unique case (i.e., first-degree articles; Figure 2). The reported offenses are mainly found in the center of Sweden, and the only municipalities that had been affected more than once were Karlskoga and Avesta (Figure 1e).

Targeting rabbit production seems to be a more recent phenomenon, with a peak in 2019 (Figure 4). Theft and burglary dominate (Figure 3), and most of these cases seem to have happened at night, while offenses such as home invasion were mainly committed during the daytime. One example of night-time burglary was reported in an article from October 2014, where offenders arrived by car during the night and took advantage of the dark to take the rabbits, but the farmers did not find out about the crime until the next day when they went to feed their animals. Offenders also posted a picture of the stolen rabbits, and seemingly bragged about the incident (Nylén, 2014). Escaping without detection also seemed to typify the situational conditions of crimes against rabbit farmers.

\section{Discussion of the Results}

\section{The Spatiotemporal Nature of CAAP}

Although mink farmers dominated the media coverage of CAAP in Sweden in the last decade, the types of offenses targeting these farmers differed. The media analysis indicates that mink farmers had a higher share of offenses directed at their persons and their families (such as assault and unlawful threats), rather than at the animals or the farm itself. This could perhaps reflect the more controversial aspect of the fur industry compared with meat and milk production. While rabbit and pig farmers mainly experienced theft of live animals, mink farmers were targeted by theft when the animal was already dead (i.e., stealing dead animals or animal products).

There exist situational conditions that are inherent to the farm environment that facilitate the execution of CAAP. For example, rurality seems to play a role in crime commission. CAAP occur when the conditions are such that the benefits of committing a crime outweigh the cost, suggesting that a lack of surveillance in remote areas (anonymity) is a crucial element influencing where CAAP occurs - a lack of guardianship reduces the chance of being caught (Cohen \& Felson, 1979). However, these farms tend to be close to larger cities. Media articles described the fact that the overall size and layout of rural properties made it difficult to be alert and maintain guardianship of the facilities. A recurrent fact was that crimes were detected the day after they occurred because they were often committed during the night. Furthermore, most farms are usually attended by only a handful of people, often the farmer and close family, and the low population density of rural areas offers 
few other possible witnesses. This implies that farms, as potential crime locations, may be highly vulnerable and suffer from security issues that are indeed situational, which could possibly be prevented through different proactive and deterring measures, such as surveillance equipment or security alarms. In addition, practices described in the articles, such as "keeping barn doors unlocked," although facilitating fire safety, also seem to have greatly facilitated trespassing, in particular, in several cases in which animal activists were suspects of these crimes.

The motivations behind these criminal acts can be difficult to identify via the media articles' descriptions of the cases, but for burglaries and thefts, for example, the motivation can clearly be associated with financial gain (especially for thefts of minks and rabbits). As initially hypothesized, these animals and animal products can be considered CRAVED goods (Clarke, 1999). Mink farmers in particular often handle animals and animal products worth millions of Swedish crowns and therefore become attractive targets by owning both valuable equipment (e.g., machinery) and goods.

Trespassing and threats against farmers were often associated with political acts. Articles of this type often linked these crimes to animal rights activists as suspects. Two major cases dominated the CAAP media coverage in the last decade. First, the so-called "Pig scandal" in 2009 when a series of films about pig farms were made when animal rights activists trespassed on properties and then shared the films over a variety of media channels. A similar peak in the number of articles in 2014 was observed regarding mink farmers. There has been a shift in the public discourse from farmers being accused as "criminals" (alleged animal abuse by animal rights activists and society in general) to becoming "victims" as most of them were freed in court. Most of the victimization carried out by animal rights activists seemed to have underlying, self-proclaimed "noble intentions" that can be linked to the techniques of neutralization as described by Sykes and Matza (1957) to morally justify the offenses for themselves and others.

Most prominently, three different neutralization techniques have been observed. There is a "denial of the victim," where the offender vilified the farmer into an oppressor who deserved to be subjected to crime. Then there is the "appeal to higher loyalties," when the offender claimed that they needed to save the animals because of alleged negligence and/or abuse, personal reasons (e.g., promoting "veganism"; Freeman, 2010), or loyalty to their organization (Schoultz \& Flyghed, 2016) and/or additional causes other than animal rights (Ellefsen, 2018). And finally, there is the "denial of injury," as when activists argued that they had only entered through unlocked doors and as such had caused no damage to anyone (as it was argued during the "Pig scandal" in 2009). Other techniques of neutralization are not as common in the cases reported in the CAAP articles but may be applicable. An example of "condemning the condemners" may be observed in the case of the "Pig scandal," as some claimed that it was hypocritical to penalize activist trespassing while not penalizing the farmers for the (alleged) poor living conditions of the animals.

Multiple techniques of neutralization may offer further insight into why these CAAP occurred. From what is written in the media archives, we observed the simultaneous use of "denial of the victim" and "appeal to higher loyalties" by offenders. For instance, on September 4, 2019, up to 1,500 minks were released from a farm in Tingsryd municipality, where a police report of trespassing, vandalism, and animal abuse was filed. An activist group later admitted to the deed in an email sent to SVT (Sweden's national television). Their intentions were made clear as they wrote, expressing hope that the minks would be able to live free in the forest and bathe in lakes:

We gave [the minks] a helping hand by taking down the fence and opening all the cages (Bengtsson, 2019).

However, these intentions did not always translate into desirable consequences for either party (victim or offender). The animals would not be able to survive in the wild, would likely attack 
each other and other animals due to stress, would disrupt surrounding ecosystems, and/or would get killed by traffic.

Regardless of the above personal or group motivations described previously, the situational conditions of these crimes play an important role in explaining the concentration of these crimes in the middle and southern parts of Sweden. These farms have a relatively higher level of accessibility in these regions compared to other regions in Sweden. Furthermore, most of the affected farms were localized close to larger town or city centers and accessible road networks, yet with low guardianship.

\section{Potentialities and Challenges of Using Articles of Media Archives}

One of the biggest advantages of using articles from media archives as data sources is that they are often free and easily available access in libraries, covering country-wide data sources, some also international. Data is rich in information from the news articles that can provide further details on the crime such as background on victim, offender, and situational circumstances. In addition, the data collected after being stored and categorized may help reveal crimes that have not (yet) been reported to police. Table 4 summarizes the potentialities and challenges in using this type of data source to detect CAAP and rural crimes in general.

However, extracting information from media archives is not problem-free. There are issues of data validity, reliability, and generalizability that should be considered. Validity regards how well media archives capture and measures the intended data (in this case CAAP), while reliability indicates the consistency of the captured data (Ceccato, 2019; Kelley, 1972). The reliability of media archives could in certain aspects be considered relatively high, as the nature of archiving implies a high ability to reproduce the results, provided the choice of keywords and time period are identical. However, if another time period is chosen, one must take into account that the evidence of newspapers is time dependent, meaning that certain crimes, victims, and offenders will be reported at a greater or lesser rate just because of the nature of media data. Also, the manual selection and interpretation of the data by the researcher implies in a subjective dimension of the process, which could as such affect the replicability of the end results. In terms of generalizability, Leung (2015, p. 325) reminds us that most qualitative research is meant to study an issue under specific circumstances (in a certain population of a focused locality in a particular context), hence generalizability of the findings (from media archives) is usually "not an expected attribute of this type of research." An alternative is to adopt same criteria for validity, namely to "use systematic sampling, triangulation and constant comparison, and documentation."

Table 4. Potentialities and Challenges of Using Media Archives.

\begin{tabular}{|c|c|}
\hline Potentialities & Challenges: validity, reliability \& generalizability \\
\hline $\begin{array}{l}\text { - Free-of-charge and relatively easy access } \\
\text { (media archives) }\end{array}$ & $\begin{array}{l}\text { - Time-consuming if the analysis is done manually. Automation } \\
\text { demands machine learning algorithms. }\end{array}$ \\
\hline $\begin{array}{l}\text { - Large database covering country-wise/ } \\
\text { international }\end{array}$ & $\begin{array}{l}\text { - Compared with official crime statistics, data flow is "messy" to be } \\
\text { collected, uncategorized, and contains doublets, subjective } \\
\text { process, for example, in the selection of keywords. }\end{array}$ \\
\hline - Data is rich in information & $\begin{array}{l}\text { - Events and details of events may be inaccurate, biased/nonfactual } \\
\text { (e.g., allegations). }\end{array}$ \\
\hline $\begin{array}{l}\text { - Reveal "whistleblowers" (crime on "the } \\
\text { on-set") }\end{array}$ & $\begin{array}{l}\text { - Dependent on keywords, and media may use multiple/nonformal } \\
\text { terminology for offenses }\end{array}$ \\
\hline $\begin{array}{l}\text { - May help reveal crime that has not been } \\
\text { reported to police }\end{array}$ & $\begin{array}{l}\text { - Risk of over/underrepresenting, sensationalism bias/politically } \\
\text { dependent }\end{array}$ \\
\hline
\end{tabular}


In terms of validity, the use of media archives to measure victimization comes with a number of problems. Certain news reports do not provide enough details about certain sought dimensions, most often of the exact type of offense included (e.g., the victim did not know what had happened besides trespassing, no exact crime code or definition) or the exact municipality the offense had taken place in (instead the article could name a region or names of cities that apply to multiple places). In most cases, separate searches on general search engines such as Google often managed to help with filling in the missing information.

Media analysis is limited by the scope of media attention, which tends to report on provocative issues that boost readership and may not cover other types of CAAPs, such as threats against farmers' family members or crimes against property. Conversely, local newspapers in certain municipalities are more associated with agriculture and animal husbandry (e.g., Sölvesborg municipality where most of the Swedish mink industry is located, or newspapers such as Lantbrukets Affärstidning [ATL]) risk creating a certain positive bias toward farmers and potentially causing an overrepresentation of a problem. Where in a certain newspaper a farmer can be painted as the offender, for example, of animal abuse, another could portray him/her as a victim, for example, of trespassing, and these definitions of offender and victim may also vary over time even within the same news source (notable example: the "Pig Scandal"; Efendić, 2009).

The use of this type of data is time-consuming if done manually-as it was done in this study. Machine learning algorithm methods are needed. Web news articles are now being generated in continuous, time-varying, and rapid modes which need to be stored, processed, and analyzed in realtime. Research is currently exploring new methods to work, for instance, with web news to handle a high volume of data streams (Za' in et al., 2017) to be able to make such data useful. As suggested by Umair et al. (2020), there is a clear potential on this vast amount of information coming from archives to detect and predict crime locations but also predict patterns and transform them into useful information in crime prevention.

In terms of content, although previous research has shown that there is a correlation between the number of crimes recorded by the police, and the number reported in newspapers (Ceccato \& Uittenbogaard, 2013; Stassen \& Ceccato, 2020), the total number and locations of these crimes reported in the media have to be considered cautiously. This is because the search for articles is dependent on the researcher's experience and capacity to seek and search through the articles and select the ones that are relevant and exclude those that are not. Informal language and misuse of terms by newspapers may affect the media archive searches. In addition, there is a risk of over/underrepresenting, the sensationalism of particular sources, which may also be guided by journalistic biases and politically dependent agendas. Events and details of events may also be biased/nonfactual (e.g., allegations), and articles may not always be updated with new information regarding cases, automatic reassessments need to be built in to be able to track cases over time. Finally, some studies claim that media reports (more specifically social media) may be better suited for reporting fear of crime rather than actual crime trends (Prieto Curiel et al., 2020).

\section{Conclusions and Recommendations}

Using printed, digitally accessible newspaper articles from media archives from 2009 to 2019 about crimes against mink, pig, or rabbit production, the study investigated types, frequency, location, and potential mechanisms of CAAP while drawing from a set of criminological theories. The results revealed specificities of CAAP cases, which provided insight into what individual-level motivations (of animal rights activists in particular) can help explain macro-level patterns of offenses.

Most of the newspaper articles are the so-called second-degree articles, namely, they cover or follow up on an investigation or describe multiple events or summarize crimes in a region, implying that the use of GIS mapping was therefore impaired by the lack of georeferenced information. The 
study offers a methodological contribution that is broadly relevant. Because official statistics on CAAP are limited or nonexistent, we utilized articles from printed, digitally available media archives as a source of information about such crimes. The use of media archives has proven to be successful for obtaining a general perspective of CAAP, but it also indicates that the use of this type of data for investigating its spatiotemporal nature is not problem-free. In addition, articles from media archives can be problematic as data sources, in particular, for estimating the exact incidence of CAAP. Articles may reflect the newsworthiness of a story (e.g., some stories are chosen over others) and/ or the sensationalist and partisan nature of commercial media. Even though media archives data are free and easily accessible, data can be "messy," uncategorized, and contain doublets compared with official crime statistics. All these challenges can affect data validity, reliability, and generalizability when using articles from media archives as data sources.

The media analysis indicated that mink production had a higher share of offenses directed at the farmers' persons and their families (such as assault and unlawful threats) than at the animals or the farms themselves, while pig and rabbit farmers more often experienced property crimes or theft. This means that, as we expected, CAAP seems to be linked to two types of motivations, financial and political, and the motivation varies by animal type. There were also indications of seasonal variations for rabbit- and pig-related CAAP (for pigs, around Christmas time, for example) but a more in-depth analysis would be desirable to assess these links between potential demand and, for example, theft.

There exist a number of situational conditions, seemingly inherent to the farm environment that facilitated the execution of CAAP. Crimes occur when the conditions are such that the benefits of committing a crime outweigh the cost, suggesting that a lack of surveillance in remote areas (anonymity) is a crucial element influencing where CAAP occurs. We have observed that CAAP occurred when a lack of guardianship (linked to rurality and limited staff presence) and good accessibility to a target (linked to being localized relatively close to a larger town and on a good road network) combine to create an increased risk of victimization and a reduced chance that the offenders are caught. Furthermore, some farms are locally united in organizations and this per se attracts animal rights activists, for example. In general, however, it should be pointed out that the overall observed pattern, in terms of the location of CAAP on a national scale, is also a consequence of where there exist opportunities for CAAP, as most farms are located in the middle and southern parts of Sweden.

When the motivation was financial, perpetrators engaged in "denial of injury" to property (victims get reimbursed via insurance policies) and looked for hot products, easy to steal and disposable (Clarke, 1999). However, when the motivation was political, as with suspects from animal rights groups, the mechanisms were different. They also engaged in "denial of injury" when they broke into farms, damaged property, and opened the animals' cages. But in addition, the neutralization techniques of "appeal to higher loyalties" and "denial of the victim" offer further explanations as to why animal activists were suspected of breaking the law by damaging property, making threats against farmers and their families, and employees. The cases illustrated that when such suspects engaged in "denial of the victim" ("they deserve it") or they "appealed to higher loyalties," by legitimizing their actions on behalf of the common good, here the welfare of animals. This study has focused on farmers as victims but future research could explore the use of techniques of neutralization to explain offenses committed by farmers on farms, such as improper/extensive use of chemical fertilizers that poison the environment, theft wages, or tax evasion.

This study also makes an important theoretical contribution related to the CRAVED model (Clarke, 1999). Our findings call for the need to adjust the CRAVED model beyond the urban context. We argue that although these animals are hot products, little is known about the links between "product attractiveness" and crime commission in rural contexts. Although "pigs" may be not considered a "typical" hot product in the traditional sense of being concealable and or easy "to be moved" (in the local market), we argue that there are other situational conditions in rural areas that make pigs, for example, a "hot" product. We suggest that the anonymity of rural 
environments and their inherent lack of guardianship (large properties) facilitate the theft of pigs by allowing a truck, for instance, to be parked in the property, without arousing the neighbors' suspicion. If these pigs are also unmarked, the local market defines the demand for them.

Our findings also call for a better understanding of the underlying mechanisms of CAAP. In particular, our media analysis clearly showed shifts from farmers being accused as "criminals" of animal abuse without a trial to becoming "victims" of threats by animal rights activists. There were cases in which animal rights activists were convicted of various crimes, especially trespassing and threats against farmers and their families and employees, sometimes via the internet. Future research should follow cases in which these shifts occurred to better understand the role of criminal justice in this process and how it can be affected by changes in societal values over time and the vilification or victimization of the involved parties (here farmers and animal rights activists). Police enforcement should be better trained to deal with these cases in more targeted areas, together with local communities, but also when a crime takes place via the internet, with multiple victims, often different motivations.

It is important to note animal rights activists are not a homogeneous group. There are those who only publicly demonstrate and therefore do not commit any crime. Others are prepared to go further and, for example, trespass, break into the property, open cages, while, finally, a minority are prepared to threaten and use violence against farmers and their families and employees. In Sweden, this last group is believed to be composed of a few individuals, also connected with other extreme groups. In the future, any type of crime prevention measure needs to consider these internal groupings to be successful. Also, future case studies that engage the perpetrators and victims, as well as the situational conditions, have a greater potential to reveal details of the crime structure, including both the motivations and opportunities for crime. Despite its limitations, this study advances our understanding of the nature and patterns of CAAP in Sweden, which is an important step toward their successful prevention and also contribute to the increasing research on rural criminology, answering recent calls for further research on crime and rurality (Donnermeyer, 2016; Meško, 2020), its causality, and how to address the safety and security of rural peoples and communities.

\section{Acknowledgments}

This article is an output of the research project "Criticism, crime and threats against Swedish animal production -The perspective of Swedish farmers" headed by Professor Peter Lundqvist, Swedish University of Agricultural Sciences (SLU) in cooperation with KTH Royal Institute of Technology. Open access funding was provided by the Royal Institute of Technology. This study was funded by Swedish Farmers' Foundation For Agricultural Research, Project Number 0-18-21-139, Kst:210.

\section{Declaration of Conflicting Interests}

The authors declared no potential conflicts of interest with respect to the research, authorship, and/or publication of this article.

\section{Funding}

The authors disclosed receipt of the following financial support for the research, authorship, and/or publication of this article: This work was supported by The Federation of Swedish Farmers (LRF), (grant number 2028.4.1-609).

\section{ORCID iD}

Vania Ceccato (D) https://orcid.org/0000-0001-5302-1698 


\section{References}

Anderson, K. (1997). A walk on the wild side: A critical geography of domestication. Progress in Human Geography, 21(4), 463-485. https://doi.org/10.1191/030913297673999021

Ärlemyr, H., \& Söderberg, M. (2019, 20 November). Aktivister tog sig in på gård. Kristianstadsbladet. https:// nxt.kristianstadsbladet.se/kristianstad/tjugotal-aktivister-har-tagit-sig-in-pa-grisgard/

Barclay, E., \& Donnermeyer, J. F. (2002). Property crime and crime prevention on farms in Australia. Crime Prevention of Community Safety, 4(4), 47-61. https://doi.org/10.1057/palgrave.cpcs.8140169

Barclay, E., \& Donnermeyer, J. F. (2007). Farm victimisation: The quintessential rural crime. In E. Barclay, J. F. Donnermeyer, J. Scott, \& R. Hogg (Eds.), Crime in rural Australia (pp. 57-68). Federation Press.

Barclay, E., Donnermeyer, J. F., Doyle, B. D., \& Talary, D. (2001). Property crime victimisation and crime prevention on farms. Institute for Rural Futures.

Bengtsson, C. (2019, 12 September). 1500 minkar släpptes ut av djurrättsaktivister. Sveriges Television. https:// www.svt.se/nyheter/lokalt/blekinge/djurrattsaktivister-brot-sig-in-pa-minkfarm

Bergström, M. (2019, 24 January). Polisen storsatsar mot brottslig djurrättsaktivism i västsverige. Göteborgsposten. https://www.gp.se/nyheter/gp-granskar/polisen-storsatsar-mot-brottslig-djurrättsaktivism-i-västsveri ge-1.12711794

Ceccato, V. (2016). Rural crime and community safety. Abingdon: Routledge.

Ceccato, V. (2019). Fieldwork protocol as a safety inventory tool in public places. Criminal Justice Studies, 32(2), 165-188. https://doi.org/10.1080/09589236.2019.1601367

Ceccato, V., \& Dolmen, L. (2011). Crime in rural Sweden. Applied Geography, 31(1), 119-135. https://doi.org/ 10.1016/j.apgeog.2010.03.002

Ceccato, V., Lundqvist, P., Abraham, J, Göransson, E., \& Svennefelt, C. A. (2021). The nature of fear among farmers working with animal production. International Criminology. https://doi.org/10.1007/s43576-02100024-z

Ceccato, V., \& Uittenbogaard, A. C. (2013). Environmental and wildlife crime in Sweden. International Journal of Rural Criminology, 2(1), 23-50. http://kb.osu.edu/dspace/handle/1811/51122

Clarke, R. (1999). Hot products (Police Research Series, Issue). www.popcenter.org

Cohen, L. E., \& Felson, M. (1979). Social change and crime rate trends: A routine activity approach. American Sociological Review, 44(4), 588-608. https://doi.org/10.2307/2094589

CVE, Center mot våldsbejakande extremism. (2020). Center mot våldsbejakande extremism. https://www.cve. se/download/18.7d27ebd916ea64de53066605/1597648388647/2020_Va\%CC\%8Aldsbejakande_djurra\% CC\%88ttsaktivism.pdf

Davis, F. J. (1952). Crime news in Colorado newspapers. American Journal of Sociology, 57(4), 325-330. https://doi.org/10.1086/220967

Donnermeyer, J. F. (2016). The Routledge international handbook of rural criminology. Routledge.

Donnermeyer, J. F., Barclay, E. M., \& Mears, D. P. (2011). Policing agricultural crime. In R. I Mawby, \& R. Yarwood (Eds.), Rural policing and policing the rural: A constable countryside (pp. 193-204). Ashgate.

Donnermeyer, J. F., Jobes, P., \& Barclay, E. (2006). Rural crime, poverty and rural community. In W. S. DeKeseredy, \& B. Perry (Eds.), Advancing critical criminology: Theory and application (pp. 199-213). Lexington Books.

Efendić, N. (2009, 24 November). Larm om vanvård av svenska grisar. Svenska Dagbladet. https://www.svd.se/ larm-om-vanvard-av-svenska-grisar

Ellefsen, R. (2018). Deepening the explanation of radical flank effects: Tracing contingent outcomes of destructive capacity. Qualitative Sociology, 41(1), 111-133. https://doi.org/10.1007/s11133-018-9373-3

European Commission (n.d.). Animal welfare. Retrieved July 15, 2021 from https://ec.europa.eu/food/animals/ animal-welfare_en 
Fine, P. R., Jones, C. S., Wrigley, J. M., Richards, J. S., \& Rousculp, M. D. (1998). Are newspapers a viable source for intentional injury surveillance data? Southern Medical Journal, 91(3), 234-242. https://doi.org/ 10.1097/00007611-199803000-00004

Freeman, C. P. (2010). Framing animal rights in the "Go Veg" campaigns of U.S. Animal Rights Organizations. 18(2), 163. https://doi.org/10.1163/156853010x492015

Ghaffar, A., Hyder, A. A., \& Bishai, D. (2001). Newspaper reports as a source for injury data in developing countries. Health Policy and Planning, 16(3), 322-325. https://doi.org/10.1093/heapol/16.3.322

Johansson, J. (2020). Sveriges lantbruk våren 2020: En undersökning bland lantbrukare. Lantbrukarnas Riksförbund. [Record \#4260 is using a reference type undefined in this output style.]

Jordbruketsverket. (2018). Lantbrukets djur-Kapitel $6 \mathrm{https} / / /$ webbutiken.jordbruksverket.se/sv/artiklar/ js2019.html

Jordbruksverket (The Swedish Board of Agriculture). (2019). Jordbruksmarkens användning 2019, Slutlig statistik (use of agricultural land 2019, final statistics).

Jordbruksverket (Swedish Board of Agriculture). (2021). Djurskyddet i Sverige. Retrieved October 4, 2021 from: https://jordbruksverket.se/djur/djurskydd-smittskydd-djurhalsa-och-folkhalsa/djurskyddet-i-sverige

Kelley, T. L. (1972). Interpretation of educational measurements.

Kruse, F. (2009, 24 November). 'Jag har inget att dölja'—utpekad bonde. Göteborgsposten.

Leander, J. (2018, 17 July). Upprört när djurrättsaktivister demonstrerade vid kaninfarm. Dalarnas Tidningar. https://www.dt.se/artikel/upprort-nar-djurrattsaktivister-demonstrerade-vid-kaninfarm-bonderna-pastod-attvi-lagt-ut-doda-kaniner

Leung, L. (2015). Validity, reliability, and generalizability in qualitative research. Journal Of Family Medicine And Primary Care, 4(3), 324-327. https://doi.org/10.4103/2249-4863.161306

LRF, Lantbrukarnas Riksförbund (The Federation of Swedish Farmers). (2020). Grön entreprenör: Affärsmöjligheter i hela landet. T. F. o. S. F. LRF. https://www.lrf.se/imagevault/publishedmedia/ q29e0k2et35yvn1wzgba/Gr-n_entrepren-r_3_upplagan_sept_2018.pdf

LRF, Lantbrukarnas Riskförbund (The Federation of Swedish Farmers). (2012). Brott på landet-En undersökning bland lantbrukare. Sveriges Lantbruk.

Marsh, H. L. (1991). A comparative analysis of crime coverage in newspapers in the United States and other countries from 1960-1989: A review of the literature. Journal of Criminal Justice, 19(1), 67-79. https:// doi.org/https://doi.org/10.1016/0047-2352(91)90083-8

Mears, D. P., Scott, M. L., \& Bhati, A. S. (2007). A process and outcome evaluation of an agricultural crime prevention initiative. Criminal Justice Policy Review, 18(1), 51-80. https://doi.org/10.1177/ 0887403406294586

Meško, G. (2020). Rural criminology—a challenge for the future. European Journal of Crime, Criminal Law and Criminal Justice, 28(1), 3-13. https://doi.org/https://doi.org/10.1163/15718174-02801001

Nöremark, M., Sternberg Lewerin, S., Ernholm, L., \& Frössling, J. (2016). Swedish farmers' opinions about biosecurity and their intention to make professionals use clean protective clothing when entering the stable. Frontiers in Veterinary Science, 3, 46-46. https://doi.org/10.3389/fvets.2016.00046

Nylén, J. (2014, 9 October). Kaninfarmare drabbade av stöld. Uppsala Nya tidning. https://www.unt.se/nyheter/ osthammar/kaninfarmare-drabbade-av-stold-3407267.aspx

Philo, C., \& Wilbert, C. (2000). Animal spaces, beastly places: An introduction. In C. Philo, \& C. Wilbert (Eds.), Animals spaces, beastly places (pp. 1-36). Routledge.

Prieto Curiel, R., Cresci, S., Muntean, C. I., \& Bishop, S., \& R. (2020). Crime and its fear in social media. Palgrave Communications, 6(57), 1-12. https://doi.org/10.1057/s41599-020-0430-7

Reis, R. (1999). Environmental news: Coverage of the earth summit by Brazilian newspapers. Science Communication, 21(2), 137-155. https://doi.org/10.1177/1075547099021002003

SCB, Statistikmyndigheten (Statistics Sweden) (2019). De gröna näringarna kommunstatistik. 
Schoultz, I., \& Flyghed, J. (2016). Doing business for a "higher loyalty"? How Swedish transnational corporations neutralise allegations of crime. Crime, Law and Social Change, 66(2), 183-198. https://doi.org/10. 1007/s10611-016-9619-5

Smith, K. (2020). Desolation in the countryside: How agricultural crime impacts the mental health of British farmers. Journal of Rural Studies, 80, 522-531. https://doi.org/https://doi.org/10.1016/j.jrurstud.2020.10.037

Stassen, R., \& Ceccato, V. (2020). Environmental and wildlife crime (EWC) in Sweden 2000-2017. Journal of Contemporary Criminal Justice, 36(3), 403-427.

SvD, Svenska Dagbladet. (2019, 19 January). Kaniner släpptes ut och slogs ihjäl i sala. Svenska DagbladetSVD. https://www.svd.se/kaniner-slapptes-ut-och-slogs-ihjal-i-sala

Svensk mink. (2020). En levande landsbygd. Svenskmink. http://www.svenskmink.se/?page_id=28

Sveriges Radio (2014, 4 October). 17000 minkar släpptes ut - Djurrättsalliansen försvarar. https:// sverigesradio.se/sida/artikel.aspx?programid=91\&artikel=4066599

Swanö, L. (2017, 24 May). Fyra suggor skurna i underlivet. Värmland Folkblad.

Sykes, G. M., \& Matza, D. (1957). Techniques of neutralization: A theory of delinquency. American Sociological Review, 22(6), 664-670. https://doi.org/10.2307/2089195

Umair, A., Sarfraz, M. S., Ahmad, M., Habib, U., Ullah, M. H., \& Mazzara, M. (2020). Spatiotemporal analysis of Web news archives for crime prediction. Applied Sciences, 10(22), 8220. https://www.mdpi.com/20763417/10/22/8220 https://doi.org/10.3390/app10228220

Verdicchio, M. (2019, 21 June). Brandattentat utreds av specialgrupp i polisen: "kopplat till djurrättsaktivister". Göteborgs-posten. https://www.gp.se/nyheter/gp-granskar/brandattentat-utreds-av-specialgrupp-i-polisenkopplat-till-djurrättsaktivister-1.15744463

Weimar, A. (2018, 25 September). Efter aktivistaktionerna—minkfarm lägger ned. Lantbrukets Affärstidning. https://www.atl.nu/lantbruk/minkfarm-utanfor-hjo-lagger-ned/

Whyte, D. (2016). It's common sense, stupid! Corporate crime and techniques of neutralization in the automobile industry. Crime, Law and Social Change, 66(2), 165-181. https://doi.org/10.1007/s10611-016-9616-8

Wikström, P. O. (2006). Individuals, settings and acts of crime: Situational mechanisms and the explanation of crime. In P. O. W. R. J. Sampson (Ed.), Individuals, settings and acts of crime: Situational mechanisms and the explanation of crime (pp. 61-107). Cambridge University Press. https://doi.org/https://doi.org/10.1017/ CBO9780511489341.004

World Bank. (2018). Rural population. The World Bank Group. Retrieved May 2021, from https:/data. worldbank.org/indicator/SP.RUR.TOTL?locations=SE

Yarwood, R., \& Evans, N. (2000). Taking stock of farm animals and rurality. In C. Philo, \& C. Wilbert (Eds.), Animals spaces, beastly places (pp. 98-114). Routledge.

Za'in, C., Pratama, M., Lughofer, E., \& Anavatti, S. G. (2017). Evolving type-2 web news mining. Applied Soft Computing, 54, 200-220. https://doi.org/https://doi.org/10.1016/j.asoc.2016.11.034 